\title{
UPAYA HUKUM PERMOHONAN EKSEKUSI TERHADAP PUTUSAN NAFKAH HADHANAH (Studi Pelaksanaan Putusan Terhadap Putusan Pengadilan Agama Nomor : 0957/Pdt.G/2014/PA.MLG)
}

\author{
Tinuk Dwi Cahyani, Komariah \\ Fakultas Hukum Universitas Muhammadiyah Malang \\ Jl. Raya Tlogomas No. 246 Dau, Malang \\ Email: tinuk_cahyani@yahoo.com, komariah.g2@gmail.com
}

\begin{abstract}
The judge's ruling on the provision of a living has to be protected from legal certainty and justice in the decision Number: 0957 / Pdt.G / 2014 / PA.Mlg if the Petitioner (Defendant) is a civil servant (PNS). Implementation of the provision of income by the Petitioner (Defendant Reconciliation) to the Respondent (Plaintiff of Reconstruction) in the decision Number: 0957 / Pdt.G / 2014 / PA.Mlg. The supporting or inhibiting factor in the provision of the provision of income by the Petitioner (Defendant) to the Respondent (Plaintiff) in Decision Number: 0957 / Pdt.G / 2014 / PA.Mlg which has permanent legal force. To know the implementation of the decision, it is necessary to do research which is a sociological juridical research, using Primary data type which is a decision Number: 0957 / Pdt.G / 2014 / PA.Mlg. Data collection using the analysis of the decision that has been legally fixed (inkracht), interviews, documentation and literature study. The study was taken from the decision of the Panel of Judges in the Religious Courts of Malang and the interviews of the Respondent / Plaintiffs of Reconstruction. in order to be a reference for readers. Meanwhile, there are still obstacles in Malang education office that can not be interviewed because it is not willing to be questioned or information on the grounds there has never been a similar case. The result of research has been done by the researcher that the Petitioner / Defendant of Reconstruction does not fulfill its obligation as it existed in the ruling Decision Number: 0957 / Pdt.G / 2014 / PA.Mlg which is the basis of judge consideration already has elements of justice for the parties because it is in accordance with the circumstances and the ability of the parties to perform their respective obligations. Applicant/Defendant Rekonpensi able to carry out its obligations as an educator as well as a Civil Servant (PNS). Since the verdict was read by the Panel of Judges who had been inkracht, the Petitioner / Defendant of the Reconstruction for three years ignored or neglected his obligations (hadhanah's living). No seizure of guarantee or sanction if Petitioner / Defendant Reconcile neglects to its obligation.
\end{abstract}

Keywords: Legal Effort, Request for Execution, Court Decision of Nafkah Hadhanah

\begin{abstract}
Abstrak
Putusan hakim mengenai nafkah hadhanah bila ditanjau dari kepastian hukum dan keadilan dalam putusan Nomor: 0957/Pdt.G/2014/PA.Mlg jika Pemohon (Tergugat) adalah pegawai Negeri Sipil (PNS). Pelaksanaan nafkah hadhanah oleh Pemohon (Tergugat Rekonpensi) kepada Termohon (Penggugat Rekonpensi) dalam putusan Nomor: 0957/Pdt.G/2014/PA.Mlg. Faktor pendukung atau penghambat dalam pelaksanaan nafkah hadhanah oleh Pemohon (Tergugat) kepada Termohon (Penggugat) dalam putusan Nomor: 0957/Pdt.G/2014/PA.Mlg
\end{abstract}


yang telah berkekuatan hukum tetap. Untuk mengetahui implementasi putusan tersebut, maka perlu dilakukan penelitian yang merupakan penelitian yuridis sosiologis, menggunakan jenis data Primer yang merupakan putusan Nomor: 0957/Pdt.G/2014/PA.Mlg. Pengumpulan data menggunakan analisa putusan yang sudah berkekuatan hukum tetap (inkracht), wawancara, dokumentasi serta studi kepustakaan. Penelitian diambil dari putusan Majelis Hakim di Pengadilan Agama Malang dan wawancara terhadap pihak Termohon/Penggugat Rekonpensi. supaya bisa dijadikan refrensi bagi pembaca. Adapun masih terjadi kendala di dinas pendidikan Kota Malang yang tidak bisa dilakukan wawancara karena tidak bersedia untuk dimintai keterangan atau informasi dengan alasan tidak pernah ada kasus yang serupa. Hasil penelitian yang telah dilakukan oleh peneliti yakni Pemohon/Tergugat Rekonpensi tidak memenuhi kewajibannya sebagaimana yang ada dalam amar putusan Dalam putusan Nomor: 0957/Pdt.G/2014/PA.Mlg yang menjadi dasar pertimbangan hakim telah memiliki unsurunsur keadilan bagi para pihak karena sesuai dengan keadaan dan kemampuan para pihak untuk melaksanakan kewajiban masing-masing. Pemohon/Tergugat Rekonpensi mampu untuk menjalankan kewajibannya yang berprofesi sebagai pendidik sekaligus seorang Pegawai Negeri Sipil (PNS). Semenjak putusan dibacakan oleh Majelis Hakim yang telah berkekuatan hukum tetap (inkracht), Pemohon/Tergugat Rekonpensi selama tiga tahun mengabaikan atau melalaikan kewajibannya (nafkah hadlanah). Tidak adanya sita jaminan atau sanksi apabila Pemohon/Tergugat Rekonpensi lalai terhadap kewajibannya.

\section{Kata Kunci : Upaya Hukum, Permohonan Eksekusi, Putusan Nafkah Hadhanah}

\section{A. PENDAhULUAN}

Pemeliharaan anak (hadlanah) pada dasarnya adalah tanggungjawab kedua orang tua yang melahirkannya. Anak merupakan insan pribadi (person) yang memiliki dimensi khusus dalam kehidupannya, dimana selain tumbuh kembangnya memerlukan bantuan orang tua, faktor lingkungan juga memiliki peranan yang sangat penting dalam mempengaruhi kepribadian si anak ketika menyongsong fase kedewasaanny kelak. Anak adalah sosok yang akan memikul tanggung jawab di masa yang akan datang, sehingga tidak berlebihan jika negara memberikan suatu perlindungan bagi anak-anak dari perlakuan-perlakuan yang dapat menghancurkan masa depannya.

Dari pandangan sosial, Haditono berpendapat bahwa anak merupakan makhluk yang membutuhkan pemeliharaan, kasih sayang dan tempat bagi perkembangannya. Selain itu, dan keluarga memberi kesempatan bagi anak untuk belajar tingkah laku yang penting untuk perkembangan yang cukup baik dalam kehidupan bersama. ${ }^{1}$ Dari beberapa teminologi di atas pada prinsipnya mengandung persamaan persepsi bahwa anak adalah pribadi yang memiliki peranan penting dan strategis dalam memikul tanggung jawab masa depan bangsa. Anak mempunyai ciri dalam dimensi kehidupan yang khsuus sehingga tidak bisa dilepaskan dari peranan orang tua dalam memelihara dan mendidiknya hingga ia mencapai masa kedewasaannya.

\footnotetext{
${ }^{1}$ D.Y. Witanto,SH, Hukum keluarga: hak dan kedudukan anak luar kawin pasca keluarnya putusan MK tentang uji materiil UU perkawinan, Prestasi Pustaka, Jakarta, Juni 2012, hal. 6
} 
Seorang anak dilahirkan ke dunia melalui proses yang panjang. Menurut sudut pandang hukum tahapan proses yang dilalui sampai terjadinya peritiwa kelahiran adalah proses yang dilalui sah (legal), baik menurut hukum agama maupun hukum negara, maka ketika lahir si anak akan menyandang predikat sebagai anak yang sah. Menurut Pasal 42 UU Perkawinan menyebutkan bahwa "Anak sah adalah anak yang dilahirkan dalam atau sebagai akibat dari perkawinan sah". Perkawinan menurut hukum islam sebagai suatu perjanjian yang sangat kuat atau misaqon ghaliza, juga ditegaskan dalam pengertian yuridis perkawinan menurut pasal 2 Instruksi Presiden Nomor 1 tahun 1991 tentang Kompilasi Hukum Islam di Indonesia (selanjutnya disingkat dengan Kompilasi Hukum Islam), yaitu "Perkawinan menurut hukum Islam adalah pernikahan, yaitu akad yang sangat kuat atau misaqon ghaliza untuk menaati perintah Allah dan melaksanakannya merupakan ibadah". Selanjutnya, menurut pasal 3 Kompilasi Hukum Islam, "Perkawinan bertujuan untuk mewujudkan kehidupan rumah tangga yang sakinah, mawaddah dan rahmah".

Menurut Abdul Ghofur Anshori, dalam kehidupan rumah tangga sering dijumpai orang (suami stri) mengeluh dan mengadu kepada orang lain ataupun kepada keluarganya, akibat tidak terpenuhinya hak yang harus diperoleh atau tidak dilaksanakannya kewajiban dari salah satu pihak, atau karena alasan lain, yang dapat berakibat timbulnya suatu perselisihan di antara keduanya (suami istri) tersebut. Tidak mustahil dari perselisihan itu akan berbuntut pada putusnya ikatana perkawinan (perceraian). ${ }^{2}$

Budi susilo mempunyai pendapat yang sama dengan pendapat Abdul Ghofur Anshori seperti diuraikan di atas, dengan menjelaskan bahwa memang benar perkawinan merupakan ikatan suci antara seorang pria dan wnaita, yang slaing mencintai dan menyayangi. Sudah menjadi kebutuhan hidup mendasar, bahwa setiap insan akan menikah. Umumnya, setiap orang berniat untuk menikah sekali seumur hidupnya saja. Tidak pernah terbersit bila di kemudian hari harus bercerai, lalu menikah lagi dengan orang lain, atau memilih untuk tetap sendiri. Namun, pada kenyataannya justru bukan demikian. Tidak sedikit pasangan suami istri, yang akhirnya harus memilih berpisah alias bercerai. Faktor ketidakcocokan dalam sejumlah hal, berbeda persepsi serta pandangan hidup, paling tidak menjadi beberapa penyebab perjadinya perceraian. ${ }^{3}$

Perceraian menurut hukum agama Islam yang telah dipositifkan dalam pasal 38 dan pasal 39 UU No. 1 Tahun 1974 dan telah dijabarkan dalam Pasal 14 sampai dengan Pasal 18 serta Pasal 20 sampai dengan pasal 36 Peraturan Pemerintah Nomor 9 tahun 1975 tentang Pelaksanaan Undang-Undang Nomor 1 Tahun 1974 tentang Perkawinan (selanjutnya disingkat PP No. 9 Tahun 1975), mencakup: pertama, “cerai talak" yaitu perceraian yang diajukan permohonan cerainya oleh dan atas inisiatif suami kepada Pengadilan Agama, yang dianggap terjadi dan berlaku beserta segala akibat hukumnya sejak saat perceraian itu dinyatakan (diikrarkan) did epan sidang Pengadilan Agama; kedua, "cerai gugat", yaitu perceraian yang dijaukan gugatan cerainya oleh dan atas inisiatif istri kepada Pengadilan

\footnotetext{
${ }^{2}$ Abdul Ghofur Anshori, Hukum Perkawinan Islam (Perspektif Fiqih dan Hukum Positif), UII press, Yogjakarta, 2011, hlm. 233

${ }^{3}$ Budi Susilo, Prosedur Gugatan Cerai, Pustaka Yustisia, yogyakarta, 2008, hlm. 11
} 
Agama, yang dianggap terjadi dan berlaku beserta segala akibat hukumnya sejak jatuhnya putusan Pengadilan Agama yang telah mempunyai kekuatan hukum yang tetap.

Akibat hukum perceraian terhadap kedudukan dan perlindungan hak-hak anak menurut Pasal 41 huruf a UU No. 1 Tahun 1974 ialah baik bapak maupun ibu tetap mempunyai kewajiban memelihara dan mendidik anak-anaknya, semata-mata berdasarkan kepentingan anak, bilamana terjadi perselisihan mengenai penguasaan anak-anak, maka Pengadilan yang memberikan keputusannya. Akibat hukum perceraian terhadap anak dalam perkawinan mereka, tetapi tidak berlaku terhadap suami dan istri yang tidak mempunyai anak dalam perkawinan mereka.

Menurut Soemiyati, jika terjadi perceraian di mana telah diperoleh keturunan dalam perkawinan itu, maka yang berhak mengasuh anak hasil perkawinan adalah ibu, atau nenek seterusnya ke atas. Akan tetapi, mengenai pembiayaan untuk penghidupan anak itu, termasuk biaya pendidikannya adalah menjadi tanggung jawab ayahnya. Berakhirnya masa asuhan adalah pada waktu anak itu sudah dapat ditanya kepada siapa dia akan terus ikut.Kalau anak itu memilih ikut bapaknya, maka hak mengasuh ikut pindah pada bapak. ${ }^{4}$

Pendapat yang sama dengan pendapat Soemiyati tersebut, dikemukakan oleh Hilman Hadikusuma, yang menjelaskan bahwa bapak yang bertanggung jawab atas semua biaya pemeliharaan dan pendidikan yang diperlukan anak setelah putusnya perkawinan karena perceraian. Jika bapak dalam kenyataannya tidak dapat melaksanakan kewajibannya membiayai pemeliharaan dan pendidikan anak, maka pengadilan dapat menentukan bahwa ibu ikut memikul tanggung jawab membiayai pemeliharaan dan pendidikan anak itu. ${ }^{5}$

Akibat hukum dari perceraian terhadap anak sah yang belum mencapai umur 18 (delapan belas) tahun atau belum pernah melangsungkan perkawinan, menurut Pasal 47 ayat (1) UU No. 1 tahun 1974, anak tersebut ada di bawah kekuasaan orang tuanya selama mereka (orang tua) tidak dicabut dari kekuasannya. Dalam hukum Islam, yang dibebani tugas kewajiban memelihara dan mendidik anak adalah bapak, sedangkan ibu bersifat membantu. Ibu hanya berkewajiban menyusui anak dan merawatnya. Sesungguhnya dalam hukum Islam sifat hubungan antara orang tua dan anak dapat dilihat dari segi material, yaitu memberi nafkah, menyusukan (irdla'), dan mengasuh (hadlanah), dan dari segi immaterial, yaitu curahan cinta kasih, penjagaan dan perlindungan serta pendidikan rohani dan lain-lain. ${ }^{6}$

Pemeliharaan anak (Hadlanah), menurut penjelasan Muhammad Thalib, merupakan hak bagi anak-anak yang masih kecil, karena mereka membutuhkan pengawasan, penjagaan, pelaksana urusannya dan orang yang mendidiknya. Ibulah yang berkewajiban melakukan hadlanah ini, karena rasullah SAW bersabda: "Engkau (ibu) lebih berhak kepadanya (anak)". Hal ini dimaksudkan jangan sampai hak anak atas pemeliharaan dan pendidikannya tersia-

\footnotetext{
4 Soemiyati, Hukum Perkawinan Islam dan Undang-Undang Perkawinan (UU No. 1 tahun 1974 tentang Perkawinan), Liberty, Yogyajarta, 1982, hlm. 126.

${ }^{55}$ Hilman Hadikusuma, Hukum Perkawinan Indonesia Menurut Perundangan, Hukum Adat, hukum Agama, Mandar Maju, bandung, 207, hlm. 176

${ }^{6}$ Zahry Hamid, Pokok-Pokok Hukum Perkawinan Islam dan UU Perkawinan di Indonesia, Bina Cipta, bandung, 1978, hlm. 134
} 
siakan. Jika ternyata hadlanah dapat ditangani orang lain, umpama nenek perempuannya dan ia rela melakukkannya sedang ibunya sendiri tidak mau, maka hak ibu untuk mengasuh (hadlanah) gugur dengan sebab nenek perempuan mengasuhnya, karena nenek peempuan juga mempunyai hak hadlanah (mengasuh). ${ }^{7}$

Beberapa data awal yang dimiliki oleh peneliti mengenai putusan cerai talak yaitu: Putusan nomor: 0957/Pdt.G./2014/PA.Mlg, Putusan Nomor: 6092/Pdt.G/2015/PA.Kab.Mlg dan perkara nomor: 2447/ Pdt.G/2016/PA.Kab.Mlg. Beberapa data awal yang dimiliki oleh peneliti mengenai putusan cerai talak ini adalah beberapa contoh perkara cerai talak yang sudah incracht namun mantan suami/ayah kandung tidak melaksanakan putusan pengadilan mengenai hadhanah, hal itu diketahui oleh peneliti awal hasil melalui teknik wawancara klien yang dilakukan oleh peneliti kepada pihak mantan isteri.

Fenomena inilah yang menarik karena peneliti merasa hak-hak anak pasca perceraian orang tuanya terabaikan dan ayah kandung merasa tidak memiliki kewajiban lagi dengan alasan anak ikut ibu kandungnya, tidak ada komunikasi lagi dengan mantan istri, yang hal ini berdampak anak yang harusnya secara putusan pengadilan sudah hidup terjamin dari hadhanah yang diberi oleh ayah kandungnya, namun kenyataannya putusan pengadilan itu di indahkan dan tidak dilaksanakan oleh ayah kandung / mantan suami tersebut. Artinya di sini putusan itu hanya di atas kertas saja, yang mana anak atau mantan istri menang di atas kertas. Hadhanah tertulis jelas di putusan, namun pelaksaan atau kenyataan tidak dilaksanakan oleh pihak ayah kandung atau mantan suami, sehingga menarik untuk diteliti.

Ibu bapak, menurut agama Islam, tidak saja mempunyai kewajiban memberi makan minum kepada anak-anaknya, tetapi juga lingkungan, pendidikan, dan pembinaan akhlak wajib diperhatikan sebagaimana ditegaskan oleh Rasulullah SAW dalam hadisnya yang diriwayatkan oleh Thusi. Seluruh umat Islam wajib mengutamakan pembentukan lingkungan akhlak yang baik. Oleh karena itu, orang tua wajib mendahulukan pertimbangan agama daripada pertimbangan ekonomi dan lain-lain sebagaimana dinyatakan dalam Alquran Surah At-Taubah ayat 24. Orang yang mengaku beragama Islam, tetapi lebih mengutamakan pertimbangan ekonomi, pertimbangan di luar Allah dan rasul-Nya, mereka ini diberi pernyataan perang oleh Allah sendiri. Hal semacam ini jangan hanya dianggap semata-mata suatu teori pendidikan atau konsep psikologi, tetapi hal ini adalah kewajiban agama.

Untuk mencapai keluarga yang bahagia, dituntut adanya kasih sayang dari orang tua kepada anak. Menurut Ahmad Mudjab Mahalli dan Muhammad Syafi'i Masykur, bagi setiap orang tua, ada beberapa poin yang harus diperhatikan dalam memberikan kasih sayang kepada anaknya. Pertama, anak harus diberi nafkah yang halal, kedua, orang tua harus bersikap adil kepada anak, dan, ketiga, anak harus diberi pendidikan agama. Apabila ketiga hal ini dilupakan, maka suatu keluarga yang bahagia tidaklah akan terwujud. ${ }^{8}$ Kewajiban bapak dalam memberi nafkah terhadap anak terbatas kemampuannya, sebagaimana ditegaskan dalam Alquran (QS. AtTalaq (65): 7), yang artinya:

\footnotetext{
${ }^{7}$ Muhammad Thalib, Manajemen Keluarga Sakinah, Pro-U, Yogyakarta, 2007, hlm. 205

${ }^{8}$ Ahmad Muhjab Mahalli dan Muhammad Syafi'i Masykur, Mencapai Keluarga Bahagia, Intishar, Yogyakarta, 2004, hlm. 41
} 
Hendaklah orang (ayah) yang mampu memberi nafkah menurut kemampuannya. Dan orang (ayah) yang rezekinya sempit hendaklah memberi nafkah dari harta yang diberikan Allah kepadanya. Allah tidak membebani seseorang melainkan (sekadar) apa yang berikan kepadanya. Allah kelak akan memberikan kelapangan sesudah kesempitannya.

Anak merupakan amanat di tangan kedua orang tuanya dan kalbunya yang masih bersih merupakan permata yang sangat berharga. Jika ia dibiasakan untuk melakukan kebaikan, niscaya dia akan tumbuh menjadi baik dan menjadi orang yang bahagia di dunia dan akhirat. Sebaliknya, jika dibiasakan dengan keburukan serta ditelantarkan seperti hewan ternak, niscaya dia akan menjadi orang yang celaka dan binasa. Keadaan fitrahnya akan senantiasa siap untuk menerima yang baik atau yang buruknya dari orang tua atau pendidiknya. Inilah barangkali pesan moral Islam kepada para orang tua berkaitan dengan pendidikan anakanaknya. Orang tua sangat berkepentingan untuk mendidik dan mengarahkan putra-putrinya ke arah yang baik dan memberi bekal berbagai adab dan moralitas agar mereka terbimbing menjadi anak-anak yang dapat dibanggakan oleh kedua orang tuanya kelak di hadapan Allah SWT.

Kedudukan, hak, dan kewajiban anak dalam keluarga atau rumah tangga menurut hukum Islam telah dipositivisasi dalam Kompilasi Hukum islam, khususnya pasal 98-pasal 106. Pasal 98 Kompilasi hukum Islam memuat ketentuan definitif bahwa batas usia anak yang mampu berdiri atau dewasa adalah 21 tahun, sepanjang anak tersebut tidak bercacat fisik maupun mental tersebut mengenai segala perbuatan hukum di dalam dan di luar Pengadilan. Pengadilan Agama dapat menunjuk salah seorang kerabat terdekat yang mampu menunaikan kewajiban tersebut apabila kedua orang tuanya tidak mampu.

Pasal 104 Kompilasi Hukum Islam membebankan tanggung jawab atas semua biaya penyusuan anak kepada ayahnya. Apabila ayahnya telah meninggal dunia, maka biaya penyusuan dibebankan kepada orang yang berkewajiban memberi nafkah kepada ayah atau walinya. Penyusuan dilakukan untuk paling lama dua tahun dan dapat dilakukan penyapihan dalam masa kurang dua tahun dengan persetujuan ayah dan ibunya.

Fakta kehidupan menunjukkan bahwa tidak sedikit perkawinan yang dibangun dengan susah payah pada akhirnya bubar di tengah jalan karena kemelut rumah tangga yang menghantamnya. Akibat dari bubarnya perkawinan itu, tidak sedikit anak yang dilahirkan dari perkawinan itu menanggung derita yang berkepanjangan. Terhadap adanya perbedaan keinginan dari kedua orang tua anak tesebut, timbul berbagai masalah hukum yang dibawa ke pengadilan dalam bentuk kasus sengketa hak asuh anak. Apabila sengketa hak pengasuhan (hadlanah) ini tidak dapat diselesaikan secara damai melalui prosedur mediasi, maka pada akhirnya harus ditempuh peneyelesaian melalui jalur litigasi dengan putusan pengadilan. Permasalahannya ialah, ketika putusan itu telah dijatuhkan oleh pengadilan, lalu misalnya, pihak yang dikalahkan tidak mau menyerahkan anak sebagai objek sengketa secara sukarela, maka biasanya akan ditempuh prosedur eksekusi putusan.

Mencermati problematika hukum seputar eksekusi putusan hadlanah tersebut cukup mernarik perhatian peneliti untuk membahasnya dari sudut pendang teori dan praktik karena eksekusi putusan hadlanah masih menyangkut berbagai aspek dalam pelaksanaannya. 


\section{B. RUMUSAN PERMASALAHAN}

Berdasarkan paparan latar belakang tersebut, maka yang menjadi permasalahan dalam penelitian ini adalah sebagai berikut :

1. Bagaimanakah putusan hakim mengenai nafkah hadhanah bila ditanjau dari kepastian hukum dan keadilan dalam putusan Nomor: 0957/Pdt.G/2014/PA.Mlg jika Pemohon (Tergugat Rekonpensi) adalah pegawai Negeri Sipil (PNS) ?

2. Bagaimanakah pelaksanaan nafkah hadhanah oleh Pemohon (Tergugat Rekonpensi) kepada Termohon (Penggugat Rekonpensi) dalam putusan Nomor: 0957/Pdt.G/2014/PA.Mlg ?

3. Apa faktor pendukung atau penghambat dalam pelaksanaan nafkah hadhanah oleh Pemohon (Tergugat Rekonpensi) kepada Termohon (Penggugat Rekonpensi) dalam putusan Nomor: 0957/Pdt.G/2014/PA.Mlg?

\section{METODE PENELITIAN}

\section{Alur Penelitian}

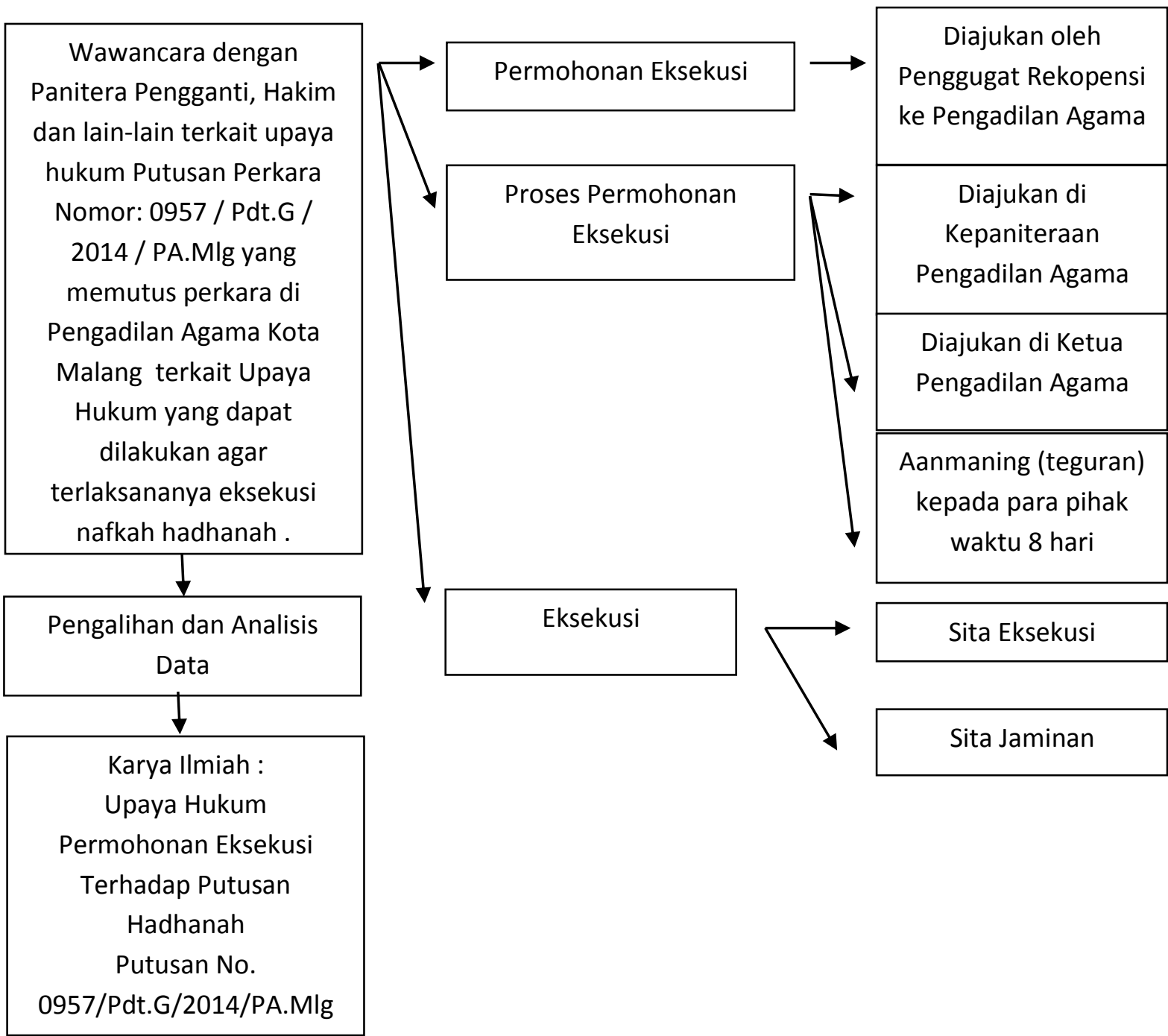


Penelitian ini merupakan penelitian yuridis sosiologis, yakni penelitian yang terjun langsung dilapangan yang didukung oleh undang-undang dan buku-buku terkait. Penelitian jenis ini mengungkapkan hukum yang hidup dalam masyarakat dalam kesehariannya (law in action). Mengingat peneliti memilih jenis penelitian yuridis sosiologis, data yang diutamakan adalah data primer, dengan tujuan untuk menemukan data tentang upaya hukum eksekusi terhadap putusan hadlanah dilapangan (putusan cerai talak Pengadilan Agama yang mempunyai hukum yang tetap). Jika (mantan) suami atau ayah kandung tidak melaksanakan putusan hadlanah, maka upaya hukum apa yang bisa dilakukan oleh (mantan istri) dan anak sah untuk menuntut hak nya berdasarkan putusan Pengadilan Agama tersebut.

\section{Lokasi Penelitian}

Penelitian ini untuk mengetahui upaya hukum eksekusi terhadap putusan hadlanah di Pengadilan Agama Kota Malang yang mengambil lokasi penelitian pada instansi yang terkait dengan upaya hukum eksekusi atas Putusan Cerai Talak dipilih sebagai lokasi penelitian karena telah memberikan putusan yang sudah mempunyai kekuatan hukum yang tetap terhadap putusan Pengadilan Agama No. 0957/Pdt.G/2014/PA.MLG.

\section{Jenis Data}

\section{a. Data Primer}

Data primer merupakan data yang diperoleh dari lokasi penelitian berupa hasil observasi, hasil wawancara dengan responden, dan dokumen yang diperoleh dillokasi penelitian yang terkait dengan permasalahan yang diangkat dalam penelitian.

b. Data Sekunder

Data sekunder merupakan data yang melengkapi data primer yang diperoleh sumber kepustakaan yang berupa hasil karya ilmiah para sarjana: berupa makalah, hasil seminar yang masih sangat relevan dengan materi penelitian. Penulis juga menggunakan karya ilmiah berupa buku-buku yang relevan dengan pokok bahasan kajian dalam penelitian ini, terutama buku-buku yang terkait dengan putusan cerai talak, eksekusi dan hadlanah. Data sekunder juga diperoleh dari peraturan perundangan terutama UU. No. 1 Tahun 1974 tentang Perkawinan dan Kompilasi Hukum Islam, serta Konvensi Hak-Hak Anak.

\section{Metode Pengumpulan Data.}

Penelitian ini merupakan penelitian yuridis empiris dengan pendekatan yuridis sosiologis. Sesuai dengan jenis penelitian, maka metode pengumpulan datanya adalah:

a. Wawancara secara mendalam atau debat interview yakni cara memperoleh informasi dengan bertanya langsung pada yang diwawancarai (responden) yang digunakan dalam penelitian ini dengan wawancara yang difokuskan, maksudnya adalah wawancara dimana responden mempunyai pengalaman-pengalaman untuk dijadikan obyek penelitian. Responden dalam penelitian ini dipilih secara purposiv sampling, yakni responden yang memiliki pengalaman menangani eksekusi terhadap putusan hadlanah, (mantan) istri yang perkara cerai talak sudah diputus 
oleh pengadilan menegani dahlanah namun (mantan) suami tidak melaksanakan putusan Pengadilan Agama.

b. Dokumentasi, yakni pengumpulan data dengan jalan mencatat dokumen-dokumen yang berkaitan dengan uapaya hukum eksekusi terhadap putusan hadlanah.

c. Kepustakaan, yakni pengkajian informasi tertulis mengenai hukum yang berasal dari berbagai sumber dan dipublikasikan secara luas serta dibutuhkan dalam penelitian hukum normatif, yakni penulisan yang didasarkan pada data-data yang dijadikan objek penelitian, seperti buku-buku pustaka, artikel, kasus-kasus hukum, dan bahan-bahan yang sesuai dengan penelitian yang akan disusun dan dianalisa, untuk dikelola lebih lanjut.

\section{Metode Analisa Data}

Analisa data dilakukan dengan cara deskriptif kualitatif, yaitu memusatkan pada masalah-masalah yang ada di masa sekarang yang bersifat aktual, kemudian data yang ada dikumpulkan, disusun, dijelaskan serta dianalisa. Jadi analisa data dalam penelitian ini merupakan prosedur pemecahan masalah yang diteliti dengan cara memaparkan data yang diperoleh dari wawancara, dokumentasi dan kepustakaan, kemudian dianalisa dan diinterpretasikan dengan memberikan kesimpulan, disajikan secara kualitatif sesuai dengan komponen permasalahan penelitian dan tujuan penelitian.

\section{HASIL DAN PEMBAHASAN}

1. Putusan Hakim Mengenai Nafkah Hadhanah Bila Ditanjau Dari Kepastian Hukum Dan Keadilan Dalam Putusan Nomor: 0957/Pdt.G/2014/PA.Mlg jika Pemohon (Tergugat) adalah Pegawai Negeri Sipil (PNS)

Dalam amar putusan Nomor: 0957/Pdt.G/2014/PA.Mlg salah satunya menyatakan bahwa : "menghukum Pemohon / Tergugat Rekonpensi untuk memberikan / membayar nafkah anakanak Penggugat Rekonpensi bernama HANIFATUL FATHNA NABILA binti Agus Wahyudi, S.Pd. (14 Tahun) dan HANIEFA AZHARI FATHNI MUFIDAH binti AGUS WAHYUDI, S.Pd. (10 Tahun) minimal sebesar Rp. 2.000.000,- (dua juta rupiah) setiap bulan diluar biaya pendidikan dan kesehatan hingga anak-anak tersebut dewasa / mandiri dengan menyerahkannya kepada penggugat";

Bahwa sudah sangat jelas apa yang disebutkan dalam amar putusan oleh hakim Pengadilan Agama yang tertera diatas. Hal ini tidak bisa dihindari oleh pemohon / Tergugat Rekonpensi untuk tidak melaksanakan kewajibannya terhadap para anaknya. Fakta yang dinyatakan oleh Termohon / Pemohon Rekopensi kepada peneliti menyampaikan bahwa paska putusan Pengadilan Agama Nomor: 0957/Pdt.G/2014/PA.Mlg yang sudah mempunyai kekuatan hukum tetap (inkracht) tidak dilaksanakan oleh Pemohon / tergugat Rekonpensi dalam hal memberikan / membayar nafkah anak-anak Penggugat dan tergugat minimal 2.000.000,- (dua juta rupiah) setiap bulan diluar biaya pendidikan dan kesehatan hingga anakanak tersebut dewasa / mandiri dengan menyerahkannya kepada Penggugat Rekonpensi.

Padahal sudah jelas ditentukan bagi pegawai Negeri Sipil (PNS), penentuan kewajiban 
untuk memberi biaya penghidupan oleh suami kepada bekas istri (selama istri tidak / belum menikah lagi dengan orang lain) dan anak, diatur dalam Pasal 8 Peraturan pemerintah Nomor 10 Tahun 1983 jo Peraturan Pemerintah Nomor 45 Tahun 1990, yaitu sebagai berikut :

"Pembagian gaji sebagaimana dimaksud ayat (1) ialah sepertiga untuk pegawai negeri sipil pria yang bersangkutan, sepertiga untuk bekas isteri, dan sepertiga untuk anak atau anak - anaknya."

Berdasarkan penjelasan pasal di atas maka pembagian gaji bagi Pegawai Negeri Sipil (PNS) yang terjadi perceraian sebagai berikut :

1. Apabila perceraian terjadi atas kehendak Pegawai Negeri Sipil pria, maka ia wajib menyerahkan sebagian gajinya untuk penghidupan bekas istri dan anakanaknya,dengan ketentuan sebagai berikut :

a. Apabila anak mengikuti bekas istri, maka pembagian gaji ditetapkan sebagai berikut:

1) Sepertiga gaji untuk Pegawai Negeri Sipil pria yang bersangkutan.

2) Sepertiga gaji untuk bekas istrinya.

3) Sepertiga gaji untuk anaknya yang diterimakan kepada bekas istrinya

2. Apabila perkawinan tidak menghasilkan anak, maka gaji dibagi dua, yaitu setengah untuk Pegawai Negeri Sipil pria yang bersangkutan dan setengah untuk bekas istrinya.

3. Apabila anak mengikuti Pegawai Negeri Sipil pria yang bersangkutan, maka pembagian gaji ditetapkan sebagai berikut :

a. Sepertiga gaji untuk Pegawai Negeri Sipil pria yang bersangkutan.

b. Sepertiga gaji untuk bekas istrinya.

c. Sepertiga gaji untuk anaknya yang diterimakan kepada Pegawai Negeri Sipil pria yang bersangkutan.

4. Apabila sebagian anak mengikuti Pegawai Negeri Sipil pria yang bersangkutan dan sebagian lagi mengikuti bekas istri, maka sepertiga gaji yang menjadi hak anak itu dibagi menurut jumlah anak.

Umpamanya : seorang Pegawai Negeri Sipil bercerai dengan istrinya. Pada waktu perceraian terjadi mereka mempunyai tiga orang anak, yang seorang mengikuti Pegawai Negeri Sipil yang bersangkutan dan yang dua orang mengikuti bekas istri. Dalam hal sedemikian, maka bagia gaji yang menjadi hak anak itu dibagi sebagai berikut :

a. (sepertiga) dari $1 / 3$ (sepertiga) gaji $=1 / 9$ (sepersembilan) gaji diterimakan kepada Pegawai Negeri Sipil pria yang bersangkutan .

b. $2 / 3$ (duapertiga) dari $1 / 3$ (sepertiga) gaji $=2 / 9$ (dua persembilan gaji diterimakan kepada bekas istrinya.

5. Apabila bekas istri yang bersangkutan kawin lagi, maka pembayaran bagian gaji itu dihentikan terhitung mulai bulan berikutnya bekas istri yang bersangkutan kawin lagi. 
6. Apabila bekas istri yang bersangkutan kawin lagi, sedang semua anak ikut bekas istri tersebut, maka 1/3 (sepertiga) gaji tetap menjadi hak anak tersebut yang diterimakan kepada bekas istri yang bersangkutan.

7. Apabila pada waktu perceraian sebagian anak mengikuti Pegawai Negeri Sipil pria dan sebagian lagi mengikuti bekas istri dan bekas istri kawin lagi dan anak tetap mengikutinya, maka bagian gaji yang menjadi hak anak itu, tetap diterimakan kepada bekas istri.

8. Apabila anak telah berusia 21 (dua puluh satu) tahun, atau 25 (dua puluh lima) tahun apabila anak tersebut masih bersekolah, yang telah/pernah kawin, atau telah mempunyai penghasilan sendiri maka pembayaran bagian gaji untuknya dihentikan. Bagian gaji yang dihentikan pembayarannya sebagai tersebut di atas, dibayarkan kepada Pegawai Negeri Sipil yang bersangkutan.

9. Apabila Pegawai Negeri Sipil pria yang telah menceraikan istrinya dan kemudian kawin lagi dengan wanita lain dan kemudian menceraikannya lagi, maka bekas istri tersebut berhak menerima :

1/3 (sepertiga) dari 1/3 (sepertiga) gaji Pegawai Negeri Sipil yang bersangkutan, apabila anak mengikuti Pegawai Negeri Sipil tersebut.

2/3 (duapertiga) dari 1/3 (sepertiga) gaji Pegawai Negeri Sipil yang bersangkutan apabila anak mengikuti bekas istri.

10. Apabila sebagian anak mengikuti Pegawai Negeri Sipil yang bersangkutan dan sebagian anak mengikuti bekas istri, maka 1/3 (sepertiga) dari 1/3 (sepertiga) gaji yang menjadi hak anak itu, dibagi menurut jumlah anak.

Menurut Gustav Randbruch, hukum harus mengandung tiga nilai identitas yaitu sebagai berikut:

1. Asas Kepastian hukum (rechmatigheid) asas ini meninjau dari sudut yuridis.

2. Asas Keadilan hukum (gerectigheit) asas ini meninjua dari filosofis dimana keadilan adalah kesamaan hak untuk semua orang didepan Pengadilan.

\section{Asas Kemanfaatan Hukum (utility) ${ }^{9}$}

Berdasarkan salah satu tujuan hukum yaitu teori kepastian hukum, teori kepastian hukum mengandung dua pengertian yaitu pertama adanya aturan yang bersifat umum yang membuat individu mengetahui perbuatan apa yang boleh dilakukan atau yang tidak boleh dilakukan, dan kedua berapa keamanan hukum bagi individu dari kesewenangan pemerintah karena adanya ataturan hukum yang bersifat umum itu individu dapat mengetahui apa saja yang boleh dibebankan atau dilakukan oleh negara terhadap individu. Kepastian hukum bukan hanya berapa pasal-pasal dalam undang-undangn melainkan juga danya konsistensi dalam putusan hakim antara putusan hakim yang satu dengan putusan hakim lainnya untuk kasus serupa yang telah diputuskan. ${ }^{10}$

\footnotetext{
9 Dwika, “Keadilan Dari Dimensi Sistem Hukum”, (02/04/2011), diakses pada 10 November 2017.

${ }^{10}$ Petir Mahmud Marzuki, 2008, Pengantar Ilmu Hukum, Jakarta : Kencana Renada Media Grup, hlm 158
} 
Kepastian hukum itu diwujudkan oleh hukum dengan sifatnya yang hanya membuat suatu aturan hukum yang bersifat umum. Sifat umum dari aturan-aturan hukum membuktikan bahwa hukum tidak bertujuan untuk mewujudkan keadilan atau kemanfaatan melainkan semata-mata untuk kepastian.

Menurut Sudikno Merto Kusumo Kepastian hukum merupakan jaminan bahwa hukum tersebut harus dijalankan dengan cara yang baik. Kepastian hukum menghendaki adanya upaya pengaturan hukum dalam perundang-undangan yang dibuat oleh pihak berwenang dan berwibawa sehingga, aturan-aturan itu memiliki aspek yuridis yang dapat menjamin adanya kepastian bahwa hukum berfungsi sebagai suatu petaraturan yang harus ditaati. Lon Fuller dalam bukunya the Morality of Law mengajukan delapan asas yang harus dipenuhi oleh hukum, yang apabila tidak terpenuhi, maka hukum akan gagal untuk disebut sebagai hukum, atau dengan kata lain harus terdapat kepastian hukum kedelapan asas tersebut sebagai berikut:

1. Suatu sistem hukum yang terdiri dari peraturan-peraturan, tidak berdasarkan putusanputusan sesal untuk hal-hal tertentu;

2. Peraturan tersebut diumumkan kepada Publik;

3. Tidak berlaku surut, karena akan merusak integritas sistem;

4. Dibuat dalam rumusan yang dimengerti oleh umum;

5. Tidak boleh ada peraturan yang saling bertentangan;

6. Tidak boleh menuntut suatu tidandakan yang melebihi apa yang bisa dilakukan;

7. Tidak boleh sering diubah-ubah;

8. Harus ada kesesuaian antara Peraturan dan Pelaksanaan sehari-hari.

Dalam penelitian inipun menyebutkan amar putusan Nomor: 0957/Pdt.G/2014/PA.Mlg salah satunya menyatakan bahwa : "menghukum Pemohon / Tergugat Rekonpensi untuk memberikan / membayar nafkah anak-anak Penggugat Rekonpensi bernama HANIFATUL FATHNA NABILA binti Agus Wahyudi, S.Pd. (14 Tahun) dan HANIEFA AZHARI FATHNI MUFIDAH binti AGUS WAHYUDI, S.Pd. (10 Tahun) minimal sebesar Rp. 2.000.000,- (dua juta rupiah) setiap bulan diluar biaya pendidikan dan kesehatan hingga anak-anak tersebut dewasa/mandiri dengan menyerahkannya kepada penggugat”, dan Pasal 8 Peraturan pemerintah Nomor 10 Tahun 1983 jo Peraturan Pemerintah Nomor 45 Tahun 1990, yaitu sebagai berikut :

"Pembagian gaji sebagaimana dimaksud ayat (1) ialah sepertiga untuk pegawai negeri sipil pria yang bersangkutan, sepertiga untuk bekas isteri, dan sepertiga untuk anak atau anakanaknya."

Dalam putusan Nomor: 0957/Pdt.G/2014/PA.Mlg yang menjadi salah satu pertimbangan hakim merujuk kepada Pasal 42 huruf b Undang-undang Nomor 1 tahun 1974 jo Pasal 105 huruf c Konpilasi Hukum Islam (KHI), Pemohon (Tergugat Rekonpensi) sebagai ayah dari anak-anak yang bernama HANIFATUL FATHNA NABILA binti Agus Wahyudi, S.Pd. (14 Tahun) dan HANIEFA AZHARI FATHNI MUFIDAH binti AGUS WAHYUDI, S.Pd. (10 Tahun), mempunyai kewajiban untuk menanggung biaya hadlanah (biaya pendidikan dan 
pemeliharaan anak) sekurang-kurangnya sampai anak tersebut dewasa atau dapat mengurus diri sendiri (21 Tahun) atau sampai anak tersebut menikah, dengan mengambil alih pendapat pakar hukum Islam dalam Kitab Al Umm juz V hal 81 menjadi pendapat Majelis Hakim dalam pertimbangan putusan ini, yang menyatakan sebagai berikut yang artinya:

"ayah diwajibkan menjamin segala sesuatu untuk kemaslahatan anaknya yang masih kecil, baik dari segi penyusuannya, nafkahnya, pakaiannya dan perawatannya".

Dan dalil dalam Kitab I'annatul thalibin Juz IV hal 99 yang artinya: “ anak yang masih mempunyai ayah dan ibu, nafkahnya menjadi kewajiban ayahnya, maksudnya walaupun anak itu telah bhalig karena istishab kepada keadaannya waktu masih kecil dan kepada hadist yang ditujukan kepada Hindhun (istri Abu Sufyan).

Yang menjadi bahan pertimbangan hakim pula dalil-dalil syar'i tersebut diatas dan berdasarkan pasal 41 huruf b undang-undang Nomor 1 tahun 1974, ayah wajib memberikan biaya / nafkah kepada anak-anaknya yang belum mencapai umur 21 Tahun, maka Majelis Hakim yang menjadi dasar pertimbangan dalam putusan inipun sudah sesuai dengan aturan hukum yang berlaku (yuridis) yang berarti unsur-unsur kepastian hukum sudah terpenuhi dalam putusan Nomor: 0957/Pdt.G/2014/PA.Mlg yang sudah inkracht.

Akan tetapi dalam pelaksanaannya tidak ada petugas atau pihak terkait yang bisa memaksa atau memiliki kewenangan dalam melaksanakan Peraturan Pemerintah Nomor 10 Tahun 1983 jo Peraturan Pemerintah Nomor 45 Tahun 1990 dan isi amar putusan Nomor: 0957/Pdt.G/2014/PA.Mlg yang telah mendapatkan kekuatan hukum tetap (inkracht). Untuk saat ini tidak ada aturan yang mengikat atau sanksi jika tidak melaksanakan isi putusan tersebut, padahal dalam kasus penelitian ini pihak Pemohon adalah seorang Pegawai negeri Sipil (PNS) yang masih aktif dan memiliki jabatan serta ikatan dinas yang sulit melaksanakannya bagaimana jika Pemohon bukan aparatur Negara bisa jadi lalai atau tidak menghiraukan sama sekali dalam isi putusan tersebut.

Tanpa kepastian hukum orang tidak tahu apa yang hurus diperbuatnya dan akhirnya timbul keresahan. Tetapi terlalu memitik beratkan kepada kepastian hukum, terlalu ketat mentaati peraturan hukum akibatnya kaku dan akan menimbulkan rasa tidak adil. Dalam bahasa praktisnya, keadilan dapat diartikan sebagai memberikan hak yang setara dengan kapastis seseorang atau pemberlakuan kepada tiap orang secara proporsional, tetapi juga bisa berarti memberi sama banyak kepada setiap orang apa yang menjadi jatahnya berdasarkan prinsip keseimbangan. Hukum tanpa keadilan tidaklah ada artinya sama sekali. Dalam putusan Nomor: 0957/Pdt.G/2014/PA.Mlg telah di awali dengan pertimbangan terlebih dahulu oleh Majelis Hakim yang memperhatikan Pasal 41 huruf a dan b undang-undang Nomor 1 tahun 1974 tentang Perkawinan mengandung klausul kemungkinan pengalihan kewajiban ayah kepada ibu untuk menanggung biaya pemeliharaan anak adalah Pasal mengenai akibat putusnya perceraian, dan klausul kemungkinan pengalihan kewajiban ayah tersebut digantungkan kepada suatu keadaan yaitu " bila mana bapak dalam kenyataan tidak dapat memenuhi kewajiban tersebut". Artinya bahwa kemungkinan pengalihan tersebut tidak seharusnya dilakukan jika tidak terbukti sebelumnya bahwa ayah dalam keadaan tidak mampu. Dan dalam perkara ini Pemohon / Tergugat rekonpensi terbukti mempunyai kemampuan dengan pekerjaan sebagai seorang Pegawai Negeri Sipil (PNS) golongan IV/a (kepala sekola). 
Dalam putusan Nomor: 0957/Pdt.G/2014/PA.Mlg yang menjadi dasar pertimbangan hakim telah memiliki unsur-unsur keadilan bagi para pihak karena sesuai dengan keadaan dan kemampuan para pihak untuk melaksanakan kewajiban masing-masing.

Menurut hasil wawancara penulis dengan hakim yang memutus perkara Nomor: 0957/Pdt.G/2014/PA.Mlg pasca putusan Pengadilan Agama yang sudah mempunyai kekuatan hukum tetap (inkracht) maka konsekuesi hukum apapun yang diberikan oleh hakim jika dalam amar putusannya tidak dijalankan oleh pihak Pemohon (Tergugat rekonpensi) maka Pengadilan Agama tidak memiliki kewenangan untuk melakukan tindakan karena tidak ada konsekuensi hukum bagi pihak yang tidak melaksanakan isi dari amar putusan tersebut. ${ }^{11}$

Hal ini sesuai dengan prinsip hakim yang bersifat pasif artinya hakim akan memberikan keadilan jika ada Permohonan atau gugatan dari pencari keadilan (Justiciabelen) dan tidak ingin mempersulit bagi para pihak pencari keadilan karena yang mulia hakim hanya bertindak sesuai dengan tugasnya yang akan dipertanggung jawabkannya baik didunia maupun diakhirat. Keadilan menurut Thomas Hubbes merupakan suatu hal perbutan yang telah dikatakan adil jika sudah didasarkan pada suatu kesepakatan yang sudah disepakati. Artinya disini jika ditinjau dari peneliti dalam putusan Nomor: 0957/Pdt.G/2014/PA.Mlg maka seharusnya para pihak melaksanakan kewajiban masing-masing yang sudah terurai didalam amar putusan.

Menurut Notonegoro keadilan merupakan suatu keadaan dimana adil jika sesuai memiliki ketentuan hukum yang berlaku. Dalam penelitian inipun hakim pada saat membuat putusan dalam amar putusannya sudah mempertimbangkan mengenai status Pemohon / Penggugat Rekonpensi sebagai Pegawai Negeri Sipil (PNS) yang terikat dalam Pasal 8 Peraturan pemerintah Nomor 10 Tahun 1983 jo Peraturan Pemerintah Nomor 45 Tahun 1990.

Dalam pertimbangan Hakim yang tertuang dalam putusan Nomor 0957/Pdt.G/2014/PA.Mlg salah satu pertimbangannya menyampaikan yakni: dalam perkara ini, Pemohon/Tergugat Rekonpensi tidak memiliki halangan apapun untuk dapatb secara rutin menafkahi anak-anaknya yang ada dalam pemeliharaan Termohon/Penggugat Rekonpensi. Pemohon/Tergugat Rekonpensi punya pekerjaan dan penghasilan tetap sebagai seorang Pegawai Negeri Sipil (PNS) Golongan IV/a (Kepala Sekolah), Pemohon/Tergugat Rekonpensi tidak menafkahi anak-anaknya selama 12 bulan (sebelum diajukan cerai thalak ke Pengadilan Agama) bukan karena persoalan ketidak mampuan atau karena adanya kendala geografir yang secara teknis menyulitkan pemenuhan nafkah tersebut, melainkan murni akibat ketiadaan rasa tanggung jawab Pemohon/Tergugat Rekonpensi untuk menunaikan kewajibannya tersebut, yang bisa dipersamakan dengan suatu tindak kesengajaan.

Sama halnya dalam amar putusan Nomor: 0957/Pdt.G/2014/PA.Mlg "menghukum Pemohon / Tergugat Rekonpensi untuk memberikan / membayar nafkah anak-anak Penggugat Rekonpensi bernama HANIFATUL FATHNA NABILA binti Agus Wahyudi, S.Pd. (14 Tahun) dan HANIEFA AZHARI FATHNI MUFIDAH binti AGUS WAHYUDI, S.Pd. (10 Tahun) minimal sebesar Rp. 2.000.000,- (dua juta rupiah) setiap bulan diluar biaya pendidikan dan kesehatan hingga anak-anak tersebut dewasa / mandiri dengan

\footnotetext{
${ }^{11}$ Wawancara dengan Hakim Pengadilan Agama Kota Malang yang bernama Dra. Hj. Laila Nurhayati, M.H. yang dilakukan pada 26 Maret 2017
} 
menyerahkannya kepada penggugat". Tidak ada alasan dan penghalang pula bagi Pemohon/Tergugat Rekonpensi untuk melaksanakan kewajibannya memenuhi nafkah hadlanah kepada anak-anaknya. Namun semenjak putusan Nomor: 0957/Pdt.G/2014/PA.Mlg berkekuatan hukum tetap (inkracht) semenjak itu pula nafkah hadlanah tidak dilaksanakan oleh Pemohon/Tergugat Rekonpensi. Dalam hal ini keadilan bagi pihak anak-anak yang seharusnya mendapatkan hak-hak nya dari Pemohon/Tergugat Rekonpensi tidak terpenuhi.

\section{Pelaksanaan Nafkah Hadhanah Oleh Pemohon (Tergugat Rekonpensi) Kepada \\ Termohon (Penggugat Rekonpensi) Dalam Putusan Nomor: 0957/Pdt.G/2014/PA.Mlg}

Dalam amar putusan Nomor: 0957/Pdt.G/2014/PA.Mlg sudah jelas menyebutkan bahwa: "menghukum Pemohon / Tergugat Rekonpensi untuk memberikan / membayar nafkah anakanak Penggugat Rekonpensi bernama HANIFATUL FATHNA NABILA binti Agus Wahyudi, S.Pd. (14 Tahun) dan HANIEFA AZHARI FATHNI MUFIDAH binti AGUS WAHYUDI, S.Pd. (10 Tahun) minimal sebesar Rp. 2.000.000,- (dua juta rupiah) setiap bulan diluar biaya pendidikan dan kesehatan hingga anak-anak tersebut dewasa / mandiri dengan menyerahkannya kepada penggugat".

Majelis Hakim dalam pertimbangannya berdasarkan putusan Nomor: 0957/Pdt.G/2014/PA.Mlg yang telah inkracht menyebutkan bahwa Penggugat / Termohon Rekonpensi menuntut agar Pemohon / Tergugat rekonpensi memberikan biaya pendidikan anak-anak mulai SD hingga ke Perguruan Tinggi, yaitu biaya pendidikan personal 2 orang anak (buku, SPP, peralatan sekolah, seragam, uang kegiatan sekolah, dll) sebesar Rp. 2.000.000,- (dua juta rupiah) perbulan dan biaya pendidikan non personal (uang pembangunan, BP3, dll) besarnya menurut ketentuan dari tiap jenjang sekolah (SMP, SMA, Universitas) serta biaya hadlanah dibebankan kepada Pemohon / Tergugat Rekonpensi tiap bulannya sebesar Rp. 4.000.000,- (empat juta rupiah), terhitung sejak perkara ini diputuskan oleh Pengadilan Agama Malang dan telah mempunyai kekuatan hukum tetap hingga anakanak tersebut menikah atau mandiri.

Namum realita atau dalam prakteknya isi amar putusan yang di sebutkan dalam putusan Nomor 0957/Pdt.G/2014/PA.Mlg tidak dilaksanakan atau diabaikan oleh Pemohon / Tergugat Rekonpensi meskipun putusan ini sudah berkekuatan hukum tetap dan sudah berlangsung kurang lebih 3 Tahun sejak di bacakan putusan oleh Majelis Hakim Pengadilan Agama Malang.

Hasil wawancara dengan Termohon / Penggugat Rekonpensi menyatakan bahwa setelah putusan tidak ada atau tidak pernah memberikan biaya hidup, pendidikan, dan kesehatan bagi kedua anaknya, namun Termohon / Penggugat Rekonpensi mengalami kebingungan untuk mencari keadilan atau meminta hak anak-anaknya yang sudah di putuskan oleh Pengadilan, sedangkan instansi tempat Pemohon/Tergugat Rekonpensi bekerja pun tidak memfasilitasi dan tidak memberikan solusi bagi Termohon/Penggugat Rekonpensi untuk memperjuang hak-hak anaknya yang masih membutuhkan biaya.

Putusan tersebut sudah 3 tahun yang lalu dan diputus oleh Majelis Hakim Pengadilan Agama Malang dan sudah mempunyai kekuatan hukum tetap, 3 Tahun bukan waktu yang singkat namun sampai sekarang kita menunggupun tidak ada nafkah yang diberikan oleh Pemohon / Tergugat Rekonpensi kepada anaknya atau melalui Termohon / Penggugat 
Rekonpensi. Padahal Pemohon / Tergugat Rekonpensi sebagai Kepala Sekolah tempat anak dari Pemohon/Tergugat Rekonpensi dan Termohon / Penggugat Rekonpensi menuntut ilmu, Termohon / Penggugat Rekonpensi menyampaikan kepada peneliti bahwa yang menjadi dasar tidak dilaksanakan kewajiban Pemohon / Tergugat Rekonpensi karena anak tidak memiliki Nomor Rekening atas nama anak. Karena alasan itu Termohon / Penggugat Rekonpensi membukakan Nomor Rekening atas nama anak Pemohon / Tergugat Rekonpensi dan Termohon / Penggugat Rekonpensi serta sudah disampaikan Nomor Rekening kepada Pemohon / Tergugat Rekonpensi namun kewajibannya tidak juga dilaksanakan. ${ }^{12}$

Seharusnya tidak ada alasan dari Pemohon / Tergugat Rekonpensi untuk tidak melaksanakan kewajibannya yang berupa nafkah hadlanah kepada anaknya karena setiap jam sekolah bertemu langsung di tempat yang sama dengan yang bersangkutan. Jika mempunyai itikat baik atau melaksanakan kewajibannya maka Pemohon/Tergugat Rekonpensi memberikan nafkah hadlanah sangatlah mudah karena sudah bertemu langsung dengan yang bersangkutan. Apalagi lagi anak telah meliliki Nomor Rekening atas nama anak Pemohon/Tergugat Rekonpensi dan Termohon/Penggugat Rekonpensi.

\section{Faktor Pendukung Atau Penghambat Dalam Pelaksanaan Nafkah Hadhanah Oleh Pemohon (Tergugat) Kepada Termohon (Penggugat) Dalam Putusan Nomor: 0957/Pdt.G/2014/PA.Mlg}

Pendapat H. Emerson sebagaimana dikutip oleh Suwarno Handayaningrat, bahwa efektifitas merupakan unsur pokok untuk mencapai tujuan atau sasaran yang telah ditentukan didalam setiap organisasi, kegiatan atau program. Disebut efektif apabila tercapai tujuan atau sasaran yang telah ditemtukan. Efektifitas adalah pengukuran dalam arti tercapainya tujuan yang telah ditentukan sebelumnya. ${ }^{13}$

Menurut peneliti dalam putusan Nomor 0957/Pdt.G/2014/PA.Mlg dalam pelaksanaan nafkah madhiyah, nafkah idhah, nafkah mut'ah kepada Termohon / Penggugat Rekonpensi dan nafkah madhiyah kepada anak-anak sudah sangat efektif karena Penggugat/Tergugat Rekonpensi wajib membayar sesaat sebelum ikrar thalaq di ucapkan, dan ikrar thalaq tidak pernah diucapkan di depan Majelis Hakim sebelum nafkah diatas dipenuhi oleh Pemohon/Tergugat Rekonpensi. Padahal disisi lain Pemohon/Tergugat Rekonpensi sangat berharap perkaranya segara diputus atau ikrar thalaq di ucapakan agar mendapatkan kepastian hukum atau status yang jelas. Dalam hal ini Pemohon/Tergugat Rekonpensi dipaksa oleh Pengadilan melalui Majelis Hakim untuk melaksanakan nafkah madhiyah, nafkah idhah, nafkah mut'ah kepada Termohon/Penggugat Rekonpensi dan nafkah madhiyah kepada anak-anak karena Pemohon/Tergugat Rekonpensi memiliki kepentingan agar perkara diputus.

Nafkah hadlanah berbeda dengan nafkah madhiyah, nafkah idhah, nafkah mut'ah kepada Termohon/Penggugat Rekonpensi dan nafkah madhiyah kepada anak-anak karena tidak ada jaminan atau retensi kepada Pemohon/Tergugat Rekonpensi, meskipun tidak melaksanakan putusan yang dalam amar putusannya berbunyi: "menghukum Pemohon / Tergugat

\footnotetext{
${ }^{12}$ Wawancara dengan Susanti, S.Pd. binti Kaswad pada 13 Maret 2017

${ }^{13}$ Soewarno Handayaningrat, Pengantar Administrasi dan Manajemen, Jakarta, CV. Haji Masagung, 1994. HIm 1
} 
Rekonpensi untuk memberikan / membayar nafkah anak-anak Penggugat Rekonpensi bernama HANIFATUL FATHNA NABILA binti Agus Wahyudi, S.Pd. (14 Tahun) dan HANIEFA AZHARI FATHNI MUFIDAH binti AGUS WAHYUDI, S.Pd. (10 Tahun) minimal sebesar Rp. 2.000.000,- (dua juta rupiah) setiap bulan diluar biaya pendidikan dan kesehatan hingga anak-anak tersebut dewasa / mandiri dengan menyerahkannya kepada penggugat”. Tidak ada kosekwuensi hukum apapun yang diberikah oleh Majelis Hakim jika perintah pada amar putusan tidak dijalankan oleh pihak Pemohon/Tergugat Rekonpensi, hal itu sesuai dengan prinsip Hakim yang bersifat pasif.

Ketika kita ingin mengetahui sejauh mana efektifitas dari hukum, maka kita pertama-tama harus bisa mengukur sejauh mana hukum itu ditaati oleh sebagian besar tarjet yang menjadi sasaran ketaatannya, kita akan mengatakan bahwa aturan hukum yang bersangkutan adalah efektif. Namun demikian, sekalipun dikatakan aturan yang ditaati itu efektif, tetapi kita masing bisa mempertanyakan lebih jauh derajat efektifitasnya karena seseorang menaati atau tidak suatu aturan hukum tergantung kepada kepentingan. ${ }^{14}$

Menurut peneliti agar putusan Nomor 0957/Pdt.G/2014/PA.Mlg dapat diterapkan khususnya mengenai nafkah hadlanahnya jika dikaitkan dengan teori efektifitas diatas yang berbunyi seseorang menaati atau tidak suatu aturan hukum tergantung kepada kepentingan maka harus ada yang dilakukan retensi atau untuk menjamin dilaksanakannya nafkah hadlanah oleh Pemohon/Tergugat Rekonpensi dalam amar putusan Nomor 0957/Pdt.G/2014/PA.Mlg harus tegas disebutkan oleh Majelis Hakim Pengadilan Agama.

Faktor pendukung/penghambat dari Pemohon/Tergugat Rekonpensi tidak melaksanakan putusan Pengadilan Agama Malang Nomor 0957/Pdt.G/2014/PA.Mlg yang sudah berkekuatan hukum tetap adalah:

1. Dalam amar putusan tidak menyebutkan jaminan bagi anak jika Pemohon/Tergugat Rekonpensi lalai melaksanakan nafkah hadlanah;

2. Intansi dimana tempat Pemohon/Tergugat Rekonpensi bekerja harusnya juga tunduk, taat dan melaksanakan putusan yang sudah dibacakan oleh Majelis Hakim yang memutus perkara Nomor 0957/Pdt.G/2014/PA.Mlg yang telah berkekuatan hukum tetap;

3. Tidak ada sanksi yang diberikan oleh instansi yang berwenang untuk memberikan punishmen kepada Pemohon/Tergugat Rekonpensi agar memaksa untuk melaksanakan amar putusan yang berbunyi nafkah anak-anak Penggugat Rekonpensi bernama HANIFATUL FATHNA NABILA binti Agus Wahyudi, S.Pd. (14 Tahun) dan HANIEFA AZHARI FATHNI MUFIDAH binti AGUS WAHYUDI, S.Pd. (10 Tahun) minimal sebesar Rp. 2.000.000,- (dua juta rupiah) setiap bulan diluar biaya pendidikan dan kesehatan hingga anak-anak tersebut dewasa / mandiri dengan menyerahkannya kepada penggugat”.

\section{E. PENUTUP}

\section{Kesimpulan}

\footnotetext{
${ }^{14}$ Ahmad Ali, menguak teori Hukum (Legal Theory), dan Teori Peradian (Judicialprudence) termasuk interpretasi undang-undang (Legis Prudence), Jakarta, Kencana, 2009, hlm 375
} 
Dari hasil penelitian di atas terhadap pelaksanaan eksekusi nafkah hadlanah Putusan Nomor: 0967/Pdt.G/2014/PA.Mlg dapat disimpulkan bahwa:

a. Bahwa Pemohon/Tergugat Rekonpensi tidak memenuhi kewajibannya sebagaimana yang tertuang dalam amar putusan padahal Pemohon/Tergugat Rekonpensi mampu untuk menjalankan kewajibannya.karena seorang Pegawai Negeri Sipil (PNS).

b. Bahwa semenjak putusan dibacakan oleh Majelis Hakim yang telah berkekuatan hukum tetap (inkracht), Pemohon/Tergugat Rekonpensi selama tiga tahun mengabaikan atau melalaikan kewajibannya (nafkah hadlanah).

c. Tidak adanya sita jaminan atau sanksi apabila Pemohon/Tergugat Rekonpensi lalai terhadap kewajibannya.

\section{Saran}

a. Diharapkan Pemohon/Tergugat Rekonpensi bisa memenuhi isi dari putusan sebagaimana dalam putusan Nomor: 0967/Pdt.G/2014/PA.Mlg Pengadilan Agama Malang.

b. Instansi atau dinas terkait bisa memaksa Pemohon/Tergugat Rekonpensi melaksanakan kewajibannya atau bisa memotong dari gajinya langsung dan dapat diberikan kepada anak-anaknya.

c. Meskipun tidak ada jaminan atau sita jaminan tapi ada sanksi yang lebih berat ketika putusan tidak dijalankan oleh Pemohon/Tergugat Rekonpensi, agar Termohon/Penggugat Rekonpensi jika ada sita jaminan dapat mengajukan permohonan eksekusi ke Pengadilan Agama Malang.

\section{DAFTAR PUSTAKA}

\section{Buku}

Abdul Manan, DR.DRS.SH.SIP, Mhum. Penerapan Hukum Acara Perdata di Lingkungan Pengadilan Agama, Penerbit Kencana, Jakarta, 2005

Abduurahman HM,SH., Hukum Acara Perdata, Penerbit Universitas Trisakti, Jakarta 1994

Andi Hamzah, DR., S.H., Kamus Hukum, Ghalia Indonesia, Cet.Pertama, Jakarta, 1986

Asshan'ani, Subulussalam, terjemahan Drs.Abu Bakar Muhammad, jilid 3, Penerbit Al Ikhlas Jakarta, 1995

Efendi Lutfi, Pokok-Pokok Hukum Administrasi, Bayu Media, Malang, 2014

Dwika, "Keadilan Dari Dimensi Sistem Hukum", (02/04/2011), diakses pada 10 November 2017.

Hensyah Syahlani, SH, Jurusita dan Penyitaan, Putusan dan Eksekusi pada Pengadilan Agama, Mahkamah Agung RI, 1990. 
Ahmad Mujahidin, DR.MH, Pembaharuan Hukum Acara Perdata Pengadilan Agama dan Mahkamah Syariah di Indonesia, IKAHI, Jakarta, 2008.

Jasmani Muzaijin, SH, Kompilasi Hukum Islam (Beberapa Titik Singgung dengan Kewenangan Pengadilan Agama), Panitia Penyuluhan Hukum Pengadilan Agama, Tarutung, 2008.

Fauzan, M Drs,SH.MM, Pokok-Pokok Hukum Acara Perdata Peradilan Agama dan Mahkamah Syar'iyah di Indonesia, Edisi Pertama -Cetakan kesatu, Penerbit Kencana, Jakarta, 2005.

Mukti Arto, H.A.Drs.S.H. Praktek Perkara Perdata Pada Pengadilan Agama, Pustaka Pelajar, Yogyakarta, 2007.

Yahya Harahap, M. SH., Kedudukan Kewenangan Eksekusi Bidang Perdata, Pustaka Kartini, Jakarta, 1992.

M. Yahya. H, Ruang Lingkup Permasalahan Eksekusi Bidang Perdata, Sinar Grafika, Jakarta, 2005 ,

Maradaman Harahap, Drs,SH.MH, Makalah Tatacara Eksekusi Putusan Pengadilan Agama, Pendidikan Calon Hakim, Anyer, 2007.

Muhammad Syafiuddin, Hukum Perceraian, Sinar Grafika, Jakarta, 2013

R. Subekti, Prof, S.H., R. Tjiptosudibio, Kamus Hukum, Cet.ke-16, Pradnya Paramita, Jakarta, 2005

R. Subekti, Prof, S.H., R. Tjiptosudibio, Kitab Undang-undang Hukum Perdata, Cet.ke-39, Pradnya Paramita, Jakarta, 2008

Retnowulan Susantio, Ny.SH dan Iskandar Oeripkartawinata,SH, Hukum Acara Perdata Dalam Teori dan Praktek, CV Mandar Maju, Bandung, 1995.

Romli Atmasasmita, Varia Peradilan Majalah Hukum No.306 Mei 2011, Ikatan Hakim Indonesia, 2011

Soewarno Handayaningrat, Pengantar Administrasi dan Manajemen, Jakarta, CV. Haji Masagung, 1994.

\section{Peraturan Perundang-undangan}

Kitab Undang-Undang Hukum Perdata

Peraturan Pemerintah Nomor 9 tahun 1975 tentang Pelaksanaan Undang-Undang Nomor 1 Tahun 1974 tentang Perkawinan

Peraturan Pemerintah Nomor 10 Tahun 1983 
Peraturan Pemerintah Nomor 45 Tahun 1990

Undang-Undang Nomor 1 Tahun 1974 Tentang Perkawinan

Undang-Undang Nomor 7 Tahun 1989

Undang-Undang Nomor 23 Tahun 2002

Herzien Inllandsch Reglement (H.I.R) Reglemen Indonesia yang Diperbaharui (R.I.B) 